\title{
ARTIKELEN
}

THEMA

\section{Lokaal bestuur in Vlaanderen en Nederland: een verkennende vergelijking}

\section{Inleiding op het themanummer 'De gemeenteraad in Vlaanderen en Nederland vergeleken'}

\author{
Marcel Boogers \& Herwig Reynaert
}

\begin{abstract}
Er zijn veel goede redenen om wat langer stil te staan bij actuele ontwikkelingen in het Nederlandse en Vlaamse lokaal bestuur en na te gaan wat beide landen van elkaar kunnen leren. Ondanks alle verschillen hebben Vlaamse en Nederlandse gemeenten namelijk meer met elkaar gemeen dan met het lokaal bestuur in Frankrijk, het Verenigd Koninkrijk, Duitse deelstaten of Scandinavische landen. Aan beide kanten van de grens worden andere woorden gebruikt, maar de taken en bevoegdheden van lokale functionarissen zijn grotendeels hetzelfde. Goede reden dus om het lokaal bestuur aan weerszijden van de grens aan een eerste vergelijking te onderwerpen, als opmaat naar de bijdragen in dit themanummer. Na een eerste duiding van de institutionele en bestuurlijke verschillen en overeenkomsten, bespreken de redacteurs van dit themanummer een aantal actuele discussies over de rol en positie van de gemeenteraad in Vlaanderen en Nederland. Ze sluiten af met een korte inleiding op de bijdragen aan dit themanummer.
\end{abstract}

\section{Institutionele gelijkenissen, bestuurlijke verschillen}

De genoemde institutionele gelijkenissen tussen het lokaal bestuur in Nederland en Vlaanderen zijn vanzelfsprekend terug te voeren op de gedeelde geschiedenis van beide landen. Voor wat betreft de vormgeving van het lokaal bestuur heeft Johan Rudolph Thorbecke hierin een belangrijke rol gespeeld. Zijn Gemeentewet van 1851 is in sterke mate geïnspireerd op het Belgische voorbeeld (zie Van der Hoeven, 1899); zijn kortstondige hoogleraarschap in Gent (1826-1830) zal zeker daaraan hebben bijgedragen (Aerts, 2018).

\subsection{Eigen dynamiek}

Alle institutionele overeenkomsten nemen niet weg dat het feitelijk functioneren van Vlaamse en Nederlandse gemeenten heel verschillend is. Ook de positie van gemeenten in het binnenlands bestuur verschilt, ondanks de grote gelijkenissen van beide grondwetten op dit punt. De politiek-bestuurlijke cultuur heeft zich in 
beide landen op een eigen manier ontwikkeld, met als gevolg dat politieke partijen in Vlaanderen een steviger greep hebben op het lokaal bestuur en op de interbestuurlijke verhoudingen dan in Nederland (Reynaert \& Steyvers, 2010; Boogers, 2010). Ook het proces van federalisering in België heeft aan de ontwikkeling van het Vlaamse lokaal bestuur een heel eigen dynamiek gegeven.

\subsection{Verschillende ervaringen}

Mede als gevolg hiervan heeft het Nederlandse en Vlaamse lokaal bestuur een andere institutionele ontwikkeling doorgemaakt. De overeenkomsten zijn nog steeds groot, maar de verschillen zijn inmiddels ook aanzienlijk. Waar het Nederlandse lokaal bestuur is gedualiseerd, kennen Vlaamse gemeenten nog steeds monistische verhoudingen. De aanstellingswijze van de burgemeester is de facto niet erg verschillend (door de raad gekozen respectievelijk door de gemeenteraad voorgedragen), maar omdat Vlaamse burgemeesters meestal over een eigen democratisch mandaat beschikken, is hun verhouding met de gemeenteraad anders dan in Nederland. De ervaringen hiermee zijn relevant in het licht van Nederlandse debatten over de gekozen burgemeester. Zo zijn er nog veel meer thema's die het waard zijn om in Vlaams-Nederlands vergelijkend perspectief te bekijken. De overeenkomsten en verschillen houden elkaar voldoende in evenwicht om vergelijkingen relevant te maken. In Bestuurswetenschappen zult $\mathrm{u}$ daarom vaker Vlaamse bijdragen aantreffen.

\section{De rol van de gemeenteraad}

Een thema dat in dit Vlaams-Nederlandse themanummer centraal staat, is de rol van de gemeenteraad en de versterking daarvan. In beide landen kampen gemeenteraadsleden met dezelfde problemen en worden ongeveer dezelfde debatten hierover gevoerd.

\subsection{Aantrekkelijkheid raadslidmaatschap}

Die debatten betreffen allereerst de aantrekkelijkheid van het ambt: de verantwoordelijkheden van raadsleden en de vergoeding die hiertegenover staat. In Nederland hebben verschillende decentralisaties het werk van gemeenteraadsleden niet alleen uitdagender, maar ook zwaarder en complexer gemaakt, en in Vlaanderen is dat eigenlijk niet anders. Daar spreekt men van een 'reglementeringsdiarree', een doolhof van technische en administratieve voorschriften dat voor een gemiddeld raadslid maar lastig te overzien is. Het aantal uren dat met het raadslidmaatschap gemoeid is, staat daarom in geen verhouding met de beperkte vergoeding die raadsleden daarvoor ontvangen. In Nederland heeft de minister reeds maatregelen aangekondigd om de ondersteuning en beloning van raadsleden te verbeteren, in Vlaanderen is dit nog onderwerp van debat.

\subsection{Beleidsbepalende en controlerende rol}

Een tweede debat dat in beide landen wordt gevoerd, betreft de beleidsbepalende en controlerende rol van de gemeenteraad. Als hoeksteen van de lokale democra- 
tie is zijn rol ten opzichte van het college vaak nog zwak. De invoering van het dualisme in 2002 heeft niet kunnen voorkomen dat de klachten hierover niet erg verschillen met die uit de monistische Vlaamse praktijk. In beide landen hoort men dat de gemeenteraad onvoldoende in staat is om het college en zijn ambtenaren goed tegenspel te bieden. In Vlaanderen hoort men dat raadsleden van coalitiefracties geen deuk in een pakje politieke boter mogen slaan vanwege de fractiediscipline, terwijl de leden van de oppositie zich schor schreeuwen tegen de wind in. In Nederland is die klacht niet veel anders: gemeenteraden staan steeds meer buitenspel (Loots \& Peeters, 2013).

\subsection{Vertegenwoordiging}

Het laatste discussiepunt gaat over de kern van het raadslidmaatschap: het vertegenwoordigen van inwoners met hun belangen en opvattingen. Hoewel de maatschappelijke functie van politieke partijen in Vlaanderen veel sterker is dan in Nederland, zijn er even grote zorgen over het vermogen van raadsleden om met recht namens hun inwoners te mogen spreken. De stembusuitslag bij gemeenteraadsverkiezingen geeft gemeenteraadsleden steeds minder een duidelijk democratisch mandaat, wat het noodzakelijk maakt dat zij - ook buiten verkiezingstijd - hun oor te luisteren leggen bij hun kiezers. 'Vertegenwoordigen is een werkwoord', heeft men in Nederland in dit verband weleens gezegd (Rob, 2016), en ook in Vlaanderen klinkt de oproep aan gemeenteraadsleden om ook buiten partijpolitiek verband in gesprek te gaan met kiezers.

\section{In dit nummer}

In dit nummer wordt alvast een eerste aanzet gegeven voor bovengenoemde debatten.

Niels Karsten en Sabine van Zuydam laten in hun bijdrage zien dat, alle inspanningen ten spijt, de rol van de vicevoorzitter in de praktijk beperkt is. Nochtans wordt er belang aan gehecht en maakt een meerderheid van de gemeenteraden ook gebruik van de bevoegdheid om een eigen vicevoorzitter aan te wijzen. Hoewel de rol van de voorzitter van de gemeenteraad in Vlaanderen noch onderschat, noch overschat moet worden, lijkt Nederland op dat vlak momenteel nog niet geneigd om in de voetsporen van Vlaanderen te stappen. Wat niet is, kan echter nog komen.

Tom Verhelst, Klaartje Peters en Koenraad De Ceuninck maken tot slot een vergelijking en evaluatie van de formele hervormingen ter versterking van de gemeenteraad in Vlaanderen en Nederland. Ondanks gelijksoortige probleemdefinities hebben beide landen voor verschillende oplossingen gekozen, die opvallend genoeg uiteindelijk toch ongeveer dezelfde resultaten opleverden. Hoe Vlaanderen kan leren van Nederland en omgekeerd. 


\section{Literatuur}

Aerts, R., Thorbecke wil het. Biografie van een staatsman, Amsterdam: 2018.

Boogers, M.J.G.J.A., Lokale politiek in Nederland. De logica en dynamiek van plaatselijke politiek, Den Haag: 2010.

Hoeven, G.G. van der, Parlementaire redevoeringen $m r$. J.R. Thorbecke betreffende het ontwerp der gemeentewet van 1851 en enkele andere onderwerpen, Arnhem: 1899.

Loots, J. \& P.H. Peeters, De gemeenteraad heeft geen toekomst. Waarom stemmen op 19 maart 2014?, Amsterdam: 2013.

Reynaert, H. \& K. Steyvers (eds.), De kerktorenpolitiek voorbij? Lokale politiek in Vlaanderen, Brugge: 2010.

Rob, 15,9 uur. De verbindende rol van het raadslid in een vitale democratie, Raad voor het openbaar bestuur, Den Haag: 2016. 